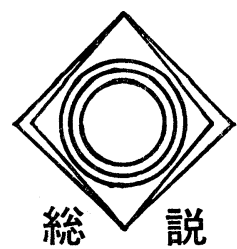

自 動 車 用 燃 料

\section{1. まえがき}

1973年秋の第 1 次石油危機以降, 各方面でエネルギ 一に対する見直しが行われている。また，1978年のイ ランの政変により, 第 2 次石油危機がおこり, 石油供 給の不安が激増してきた。現在の自動車用燃料はほと んど全部を石油系エネルギーに依存している。石油の 供給不安に対して各先進国の自動車業界では，代替原 動機，代替燃料に関する検討を行っている。代替原動 機についても数種の原動機が爼上にのぼったが，いず れも公害対策としての排気浄化用として見直された原 動機が主で，現在の焦眉の急である省エネルギーの観 点からは現行の往復動内燃機関にとって代わる原動機 は, 当分出現しそうにもない。自動車業界では原動機 の省然費化はもらろん検討しているが，自動車全体の 省燃費といら観点から, 車両重量の軽減, 走行抵抗の 減少などに力を入れている。OPECなどの政策にかん がみて, 石油は有限であるとの観点から, 早急なる自 動車用代替然料の開発が望まれている。

\section{1 燃料の可搬性}

\section{2. 自動車用燃料の具偒条件}

工場などの定置用原動機の然料はスペースさ市れ ば，燃料に対する制やくは少ない。また，動くもので あっても電車は土ネルギーを架線や線路から電流とし て補給することができ，電車そのものが然料をもつ必 要がない。これに反して, 自動車や航空機は, 自ら使 らェネルギーを，自らもたなければならない。自動車 用然料としては燃稌の可搬性といらことが大事な必須 条件である。

\section{2 常温で液体であること}

自動車用然料として必須条件ではないが，燃料が “常温で液体”であることは非常に望ましい条件であ る。その理由は次の通りである。

（1）燃料の調量が容易である。

(1) 空燃比の制御の容易性

自動車に広く使われている往復動式内然機関はもら

理事 茨城県筑波郡谷田部町苅間 2530
(財)日本自動車研究所河野 俊之

ろんであるが, 将来の自動車用原動機として期待され ているガスタービン機関にしろ，すべての燃焼機関は 燃料と空気の混合物を燃焼させるという現象からエネ ルギーを引き出している。そのためには, 空気と燃料 の比（空然比といら）を燃料の種類によって最適にす る必要がある。供給される空気量に応じて最適量の燃 料を供給するために従来から各種の制御装置が工夫さ れている。この燃料の調量の容易性からいうと, 然料 が常温で液体であることは, きわめて有益である。最 近の公害対策としての自動車の排気浄化の方策とし て, 完全然焼のため, 空燃比の精密なる制御が要求さ れている。最近のエレクトロニックスの進歩で, 空然 比の制御は, きわめて高速で, 精度良くコントロール されるよらになった。しかし, 制御装置のアクチェー ターとしては, 相手の然料が固体であったり, 気体で あるよりは，常温で液体である方がはるかに制御しや すい。

(口) 燃料の残量表示の容易性

自動車では, 燃料の残量を常時, 運転者に認知させ る必要がある。残量を容易に表示するためにも燃料の 調量の容易性は必要である。

() 燃料流通機構での使益

ガソリン・スタンドなど燃料流通機構では, 燃料の 調量が毎日の業務であり, 円滑な流通業務を達成する ためには, 燃料の調量の容易性はきわめて重要であ, る。

2. 3 単位重量, 単位容積当りの発熱量の大なるこ と

以上, 自動車用然料の具備条件を述べたが, 現在の 技術水準では少量で大カロリーを出し, 可搬性に優 れ，常温で液体であるという点で自動車用然料として 石油に優る燃料は見当たらないようである。

\section{3. 自動車用燃料の現状}

2. で述べた自動車用然料の具備条件を備えた石油 が，現在は自動車用然料の主流である。現在の自動車 用原動機にはガソリン機関とディーゼル機関の 2 種類 があり、前者にはガソリンが，後者には軽油が一般に 


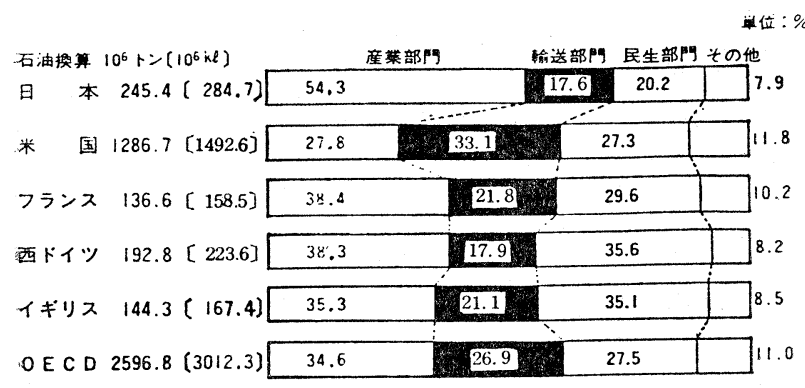

出所 : ENERGY BALANCES OF OECD COUNTRIES 図 1 部門別最終エネルギー需要（1976年）

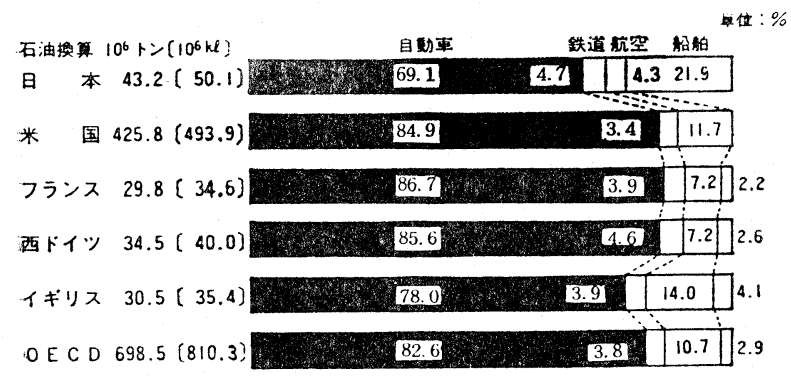

出所 : ENERGY BALANCES OF OECD COUNTRIES 図 2 翰送手段別最終エネルギー需要（1976年）

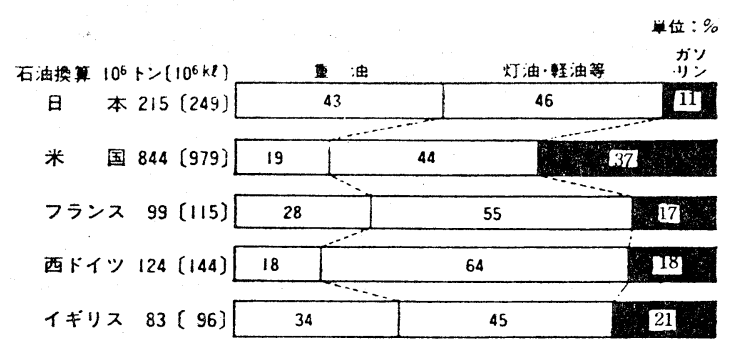

出所 : 日本 : 石油連盟, 米 : 鉱山局, 英: 中央統計局, 仏: フランス石油専門委員会, 独: 企業経営省 注：石油 $1 \mathrm{t}=$ 石油 $1.16 \mathrm{kl}$ として換算

図 3 石油製品油種別消費割合（1977年）

使われている。

3. 1 自動車のエネルギー消費割合

図 1 はエネルギー消費部門別のエネルギー需要を主 要工業国別に示したもので, 輸送部門のエネルギー需 要は日本では $17.6 \%$ で, 西独と並び他国に比べて低 い。また, 産業部門の $1 / 3$ 以下である。図 2 は輸送部門 ル和ける輸送手段別最終エネルギー需要を主要工業国 別に示したもので，輸送部門における自動車用エネル ギーの割合は欧米諸国に比べて，10～15\%も低い。図 3 は石油製品の油種別消費割合を主要工業国別に示し えもので，石油消費量に占めるガソリンの割合は $11 \%$
にしかすぎず，米国の $37 \%$ と比べて $1 / 3$ 以 下である。以上のことから，日本に和い ては，石油消費量中自動車が占める割合 は工業国中低いことが分る。

\section{2 自動車用然料の需給見通乙}

通産省の総合エネルギー調査会は昭和 54 年 8 月，東京サミットの合意を基礎に わが国の長期エネルギー需給見通しを発 表した(表1)。この見迪しに䋆けるエネ ルギーの需要の伸びは, 1985年までは年 率6.1\%，1990年までは4.4\%，1995年ま では $3.4 \%$ としている。一方，この需要 を満たすための供給は, 石油輸入量をI E A (国際エネルギー機関) の申乙合わ せを尊重して，1985年に3.66億kl（備蓄 余裕をみた下限は 3.5 億 $\mathrm{k} \ell$ ）とし，それ 以後は，この量を越えないように抑えて いる。このことは1977年の日本の全エネ ルギー消費の75\%が石油であるが，石油 の割合を1985年に63\%，1990年に50\%， 1995年には43\%に低減させようという計 画を示している。これを実現させるため には，1 次エネルギー中の石油以外のエ ネルギーの割合を毎年飛躍的に増大しな 汀ればならないことを示している。石油 以外のエネルギーとしては, 水力, 地 熱, 石炭, 天然ガス ( $\mathrm{LNG}$ ), 原子力括 よびアルコールや石炭液化油などの新然 料油がある。これら石油以外のエネルギ 一は鋭意開発が進められているが，技術 上, コスト上, 環境上などの困難が山積 している。これらのうち, 前述の自動車 用燃料の具備条件を備えている然料とし て新然料油が石油代替として最も可能性 の高いものとして考兄られる。表 1 によると新然料油 などに期待されるェネルギーの量は石油換算で1977年 に31万klであったものを1985年に 520 万kl，1990年に 3850 万l $\mathrm{kl}$ 飛躍的に桩大することが要請されている。

上記の総エネルギー需要に対し, 各産業部門別の需 要見通しは明らかにされていないが，自動車用然料 （ガソリンと軽油）に詨し，従来の消費量の趨勢と表 1 の総エネルギー需要の伸びを勘案して試算した結果 を図 4 に示す。困中，1978年までの実線は実績で，ガ ソリンは年間約 4 〜 $5 \%$ で伸び，軽油はそのとさの景気 の状況に左右されるが，5～7\%の伸びを示している。 
表 1 長期エネルギー需給暫定見通し

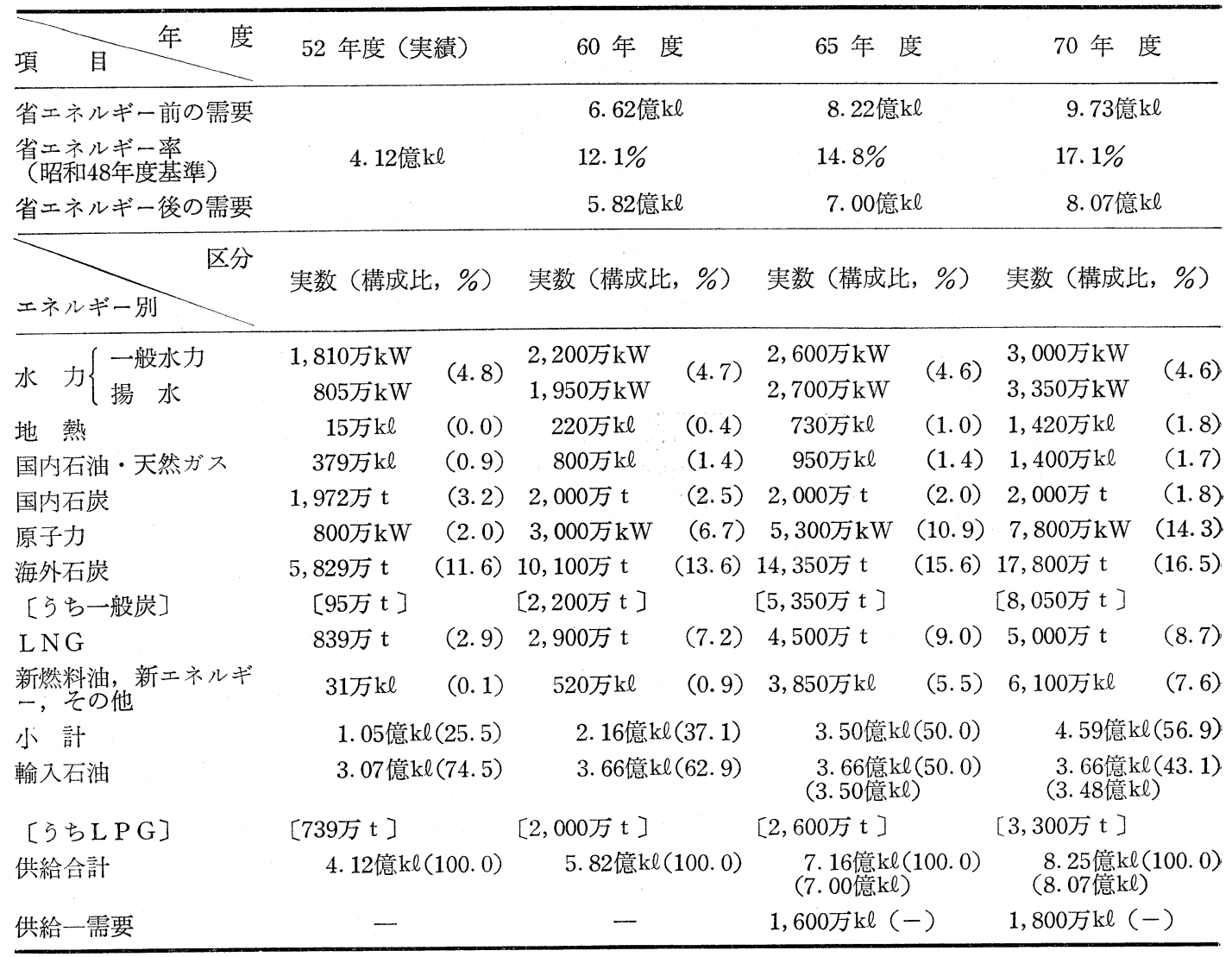

（注） 1. 石油換算は9, $400 \mathrm{kcal} / \ell$.

2. 昭和 65 年度, 70 年度の輸入石油の（）内は, 輸入石油に係る需要量

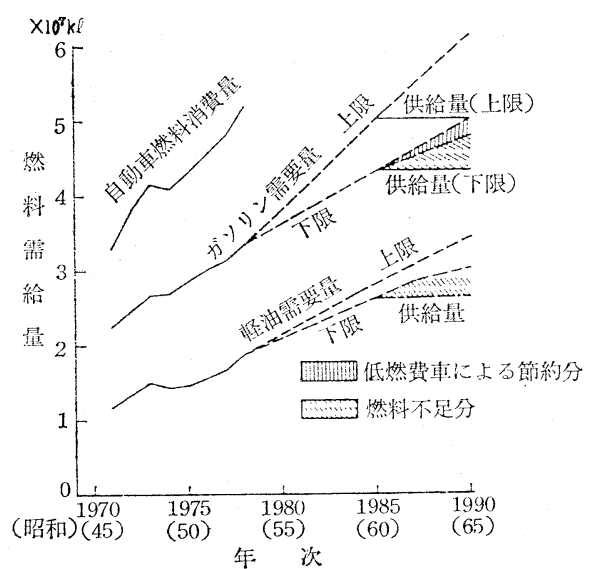

出所：自動車研究1980. 5 月

\section{图 4 自動車然料（ガソリン，軽油）の需給見通し}

そこで, 表 1 の総エネルギー需要の伸びに近く, 1985 年までは年率 $6 \%$, 1990年までは $4 \%$ の伸びと仮定し
て示したのが図 4 の上限の破線である。自動車業界は 省エネルギーの努力を払っているので, 表 1 の一般の 需要の伸びでみるのはやや過唾見積もりと思われるの で，ガソリンの需要をできるだけ抑党，1985年まで年 率 $4 \%$, それ以後 $3 \%$ として見積もったのが下限の破 線で，これは自動車産業が落ちこまないために必要な 最低限の伸び率と考学られる。これによると，1985年 にはガソリンが 4300〜 5000 万kl, 軽油 $2500 〜 2800$ 万 $\mathrm{k} \ell$ ，合計6800〜 7800万kl，1990年にはガソリン $5000 〜$ 6100 万 $\mathrm{k} \ell$, 軽油 $2900 \sim 3400$ 万 $\mathrm{k} \ell$, 合計 $7900 \sim 9500$ 万 $\mathrm{k} l$. となる。

この需要に対して, 供給の方はどうであろらか。ガ ソリンも軽油も原油の蒸留精製品であり, また一部は 重質油の分解による製品であるため, 原油の量に対応 しかつ石油精製設備が変らなければ, 各石油製品の比 率は極端に変えることはでさない。最近, 軽油の流動 点や留出温度範团を変えてその収率をあげることが論 
議されているが，それによる增量は数\%にすぎず，一 時的不足を補うだけであろう。

1978年の自動車用ガソリン, 軽油の収率は, 原油量 飞対しガソリン $14.1 \%$, 軽油 $8.4 \%$ となって和り, ガ ソリンや軽油の精製設備が急に変更されない限り,こ の比率は大きくは変らない。原油輸入量が表 1 の見通 乙通り，1985年までは年々直線的に増加してその下限 3.5 億kl飞達し，それ以後変らないといらことになれ ば,ガソリンは 1985 年で 4900 万 $\mathrm{k} \ell$, 軽油は 2900 万 $\mathrm{k} \ell$ 精製 されることとなり，図4で示す需要は何とかまかな兄 ることになる。しかし，このことはわが国の要望通り 原油が輸入された場合のことで, 先のイラン政変のよ らな国際問題が起これば輸入量は激減するし，また原 油価格の高騰は自 然輸入量の減少につながる。さら に, 原油が十分輸入されたとしても, 他のエネルギー 需要部門の石油以外のエネルギー転換と節約が見通し を下まわると，引いては自動車用燃料の量が制約をう けることになる。輸入量もエネルギー転換も順調に推 移するとすれば，1985年までは自動車用燃料は一時的 なものを除けば, 極端な燃料不足は起らず, 需要に見 合うギリギリの線で供給されるものと思われる。

問題になるのは, 1985年以降で, 原油輸入量が 3.5 億k抑光られてしまらと，それに応じて自動車然料 の量も1985年で頭打ちとなる。したがってそれ以降の 需要增は不足量となり，1990年には不足量がガソリン で700〜1000万 $\mathrm{k} \ell$, 軽油で400〜600万 $\mathrm{k} \ell$ とる。これは 1990 年の自動車用燃料の 全消費量の 14 ～18\% 飞達す る。

3. 3 自動車用燃料の不足とその対策

1985年以降の自動車用燃料の不足対策が焦眉の急で ある。昭和 54 年暮, 政府は省エネルギー法に基づく自 動車の燃費基準を定め, ガソリン乗用車の燃費 (10モ ード走行燃費）を1985年までに，平均して昭和53年度 の12.3\%改善することを自動車業界に要請した。しか し，この燃費改善車は1985年にならないと出そろわな い。1985年以降の新造車は燃費改善車でも, 既発売車 はそれより燃費が悪いので，1990年で自動車の全ガり リン消費量で5〜6\%の低減しか見こめない。上記政府 の然費基準はガソリン乗用車のみであるから，トラッ クを主体とするディーゼル車には適用されないので, 軽油の低減には拘束力はない。もちろん, 業界はディ 一ゼル車についても燃費低減の努力はしているが，そ の低減量には限度があり，上記不足量を補うほどには 到底なりそうにもない。

この不足するガソリン，軽油を補ら方法として，む
つとも望ましいのは, 重油を分解してガソリン, 軽油 を精製して供給量を増すことである。これには，他の エネルギー消費部門，とく発電所に括けるエネルギ 一転換が順調に進んで, 重油分に余裕を生じることが 前提条件で, 重油自体が不足していてはどうにもなら ない。さらに別の問題は, 重質油の分解設備の增強 で，今から早急に計画しないと間にあわない。しか も, 自動車用燃料のガソリンと軽油が上記の需要があ り, かつ今後の輸入原油が重質化の傾向にあるので, 既存の精製方法ではるかなえないと思われる。このよ うに重質油の分解精製による堌量も決して容易ではな いが，この場合には車の方はまったく変更しないです むので，その経済的利益は大きい。

燃料不足を補うもらひとつの方法は石油代替エネル ギーの利用である。石油代替エネルギーには, 先述し たように, 水力, 地熱, 石炭, 天然ガス, 原子力拈よ び新然料油がある。前 5 者は，主として発電用に用い られ，電気エネルギーとなる。自動車用燃料として電 気エネルギーを用いる試みは，古くから開発されてき た電気自動車である。

現行の往復動内燃機関用の燃料としての具備条件を 先述したが，この具備条件を備えた石油代替燃料が新 燃料油である。石油, 石炭, 天然ガス，原子力の原料 ウランは何れも化石然料といわれ有限である。無限に 近いものとして水素がある。以下，石油代替然料とし て, 新燃料油, 水素燃料などについて, 自動車用燃料 としての現状と見通しを述べることにする。

\section{4. 自動車用石油代替燃料}

電気エネルギーを除いた自動車用燃料として可能性 ある燃料の一覧表が表 2 である。常温で液体と気体に 大きく分け，液体燃料中で炭化水素の現在自動車用と して使用されている石油燃料と特性を対比して示して ある。

\section{1 新然料油}

「新然料油」の定義をまず述べて沶く。昭和54年 11 月，資源エネルギー庁が発行した『新燃料油一「エネ ルギーの谷間」を埋める石油代替流体燃料一』という 小冊子飞よると,次のよう飞定義されている。「従来の 石油然料とは原料は異なるが, 最終使用形態が同じか, または類似して抢り，その開発扣よび導入に関して早 期実現性の高い以下の 3 つの利用分野に括ける新しい 流体燃料油を総称して 新燃料油という。(四 5 参照)

（1） 天然ガス，随伴ガスなどを原料とする合成アル コールなどの既存石油製品への混入などによる利 用。 


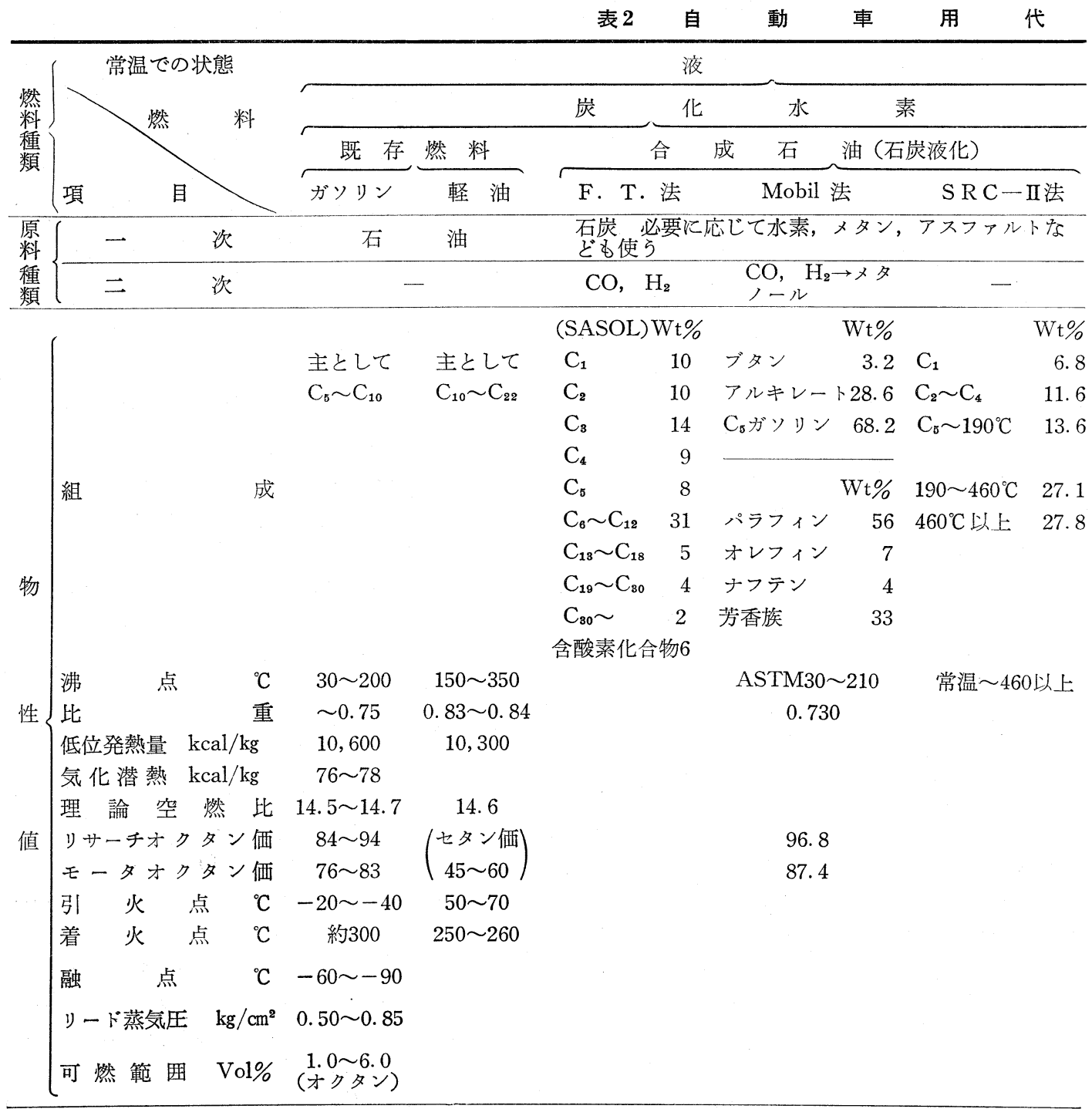

\begin{tabular}{|c|c|c|c|c|c|c|}
\hline 自 & 物性值の面でみた特色 & - & - & $\begin{array}{l}\text { ガソリンとほぼ } \\
\text { 同じ }\end{array}$ & ガソリンとほぼ同 & $\begin{array}{l}\text { ぞちらかそいえば } \\
\text { ボイラ一燃料 }\end{array}$ \\
\hline $\begin{array}{l}\text { 䡃 } \\
\text { 車 }\end{array}$ & ガソリンとの相容性 & - & & 高 & W & - \\
\hline 用 & 軽油との相容性 & - & & - & - & $w$ \\
\hline 燃 & 車載性 & - & & 既存燃料之同じ。 & ただし，材料の腐食 & 气，劣化を検討する \\
\hline $\begin{array}{l}\text { と } \\
\text { 乙 }\end{array}$ & エンジ & - & & 同 & 司 & 上 \\
\hline $\begin{array}{l}\tau \\
\text { の }\end{array}$ & 供給系の 混合なし & - & & 同 & 司 & 上 \\
\hline $\begin{array}{l}\text { 適 } \\
\text { 合 }\end{array}$ & 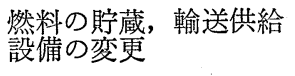 & - & & 同 & 司 & 上 \\
\hline 性 & 自動車への適合性 & - & & 同 & 上 & $\begin{array}{l}\text { ディーゼル油とな } \\
\text { り得るか要検討 }\end{array}$ \\
\hline
\end{tabular}




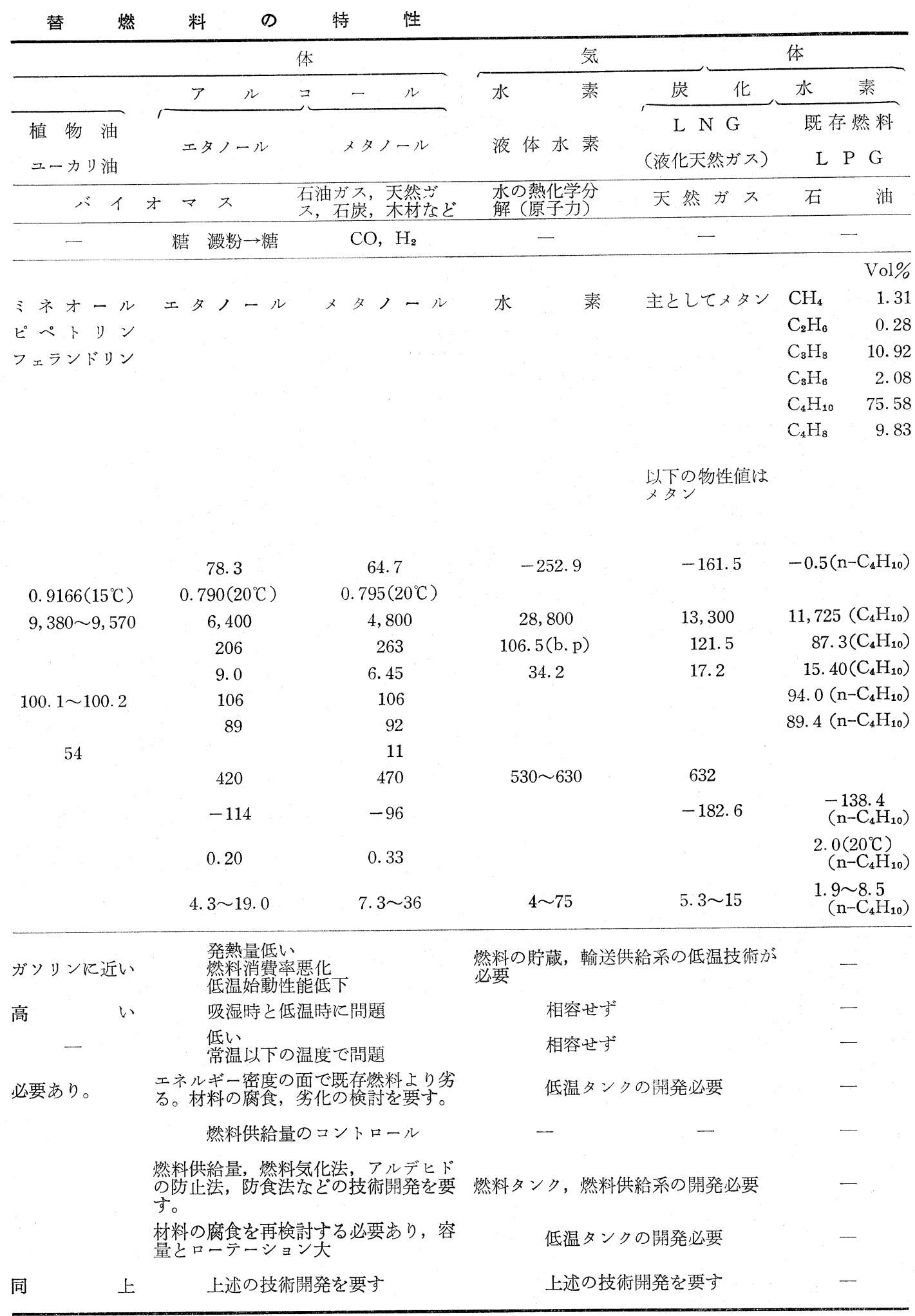




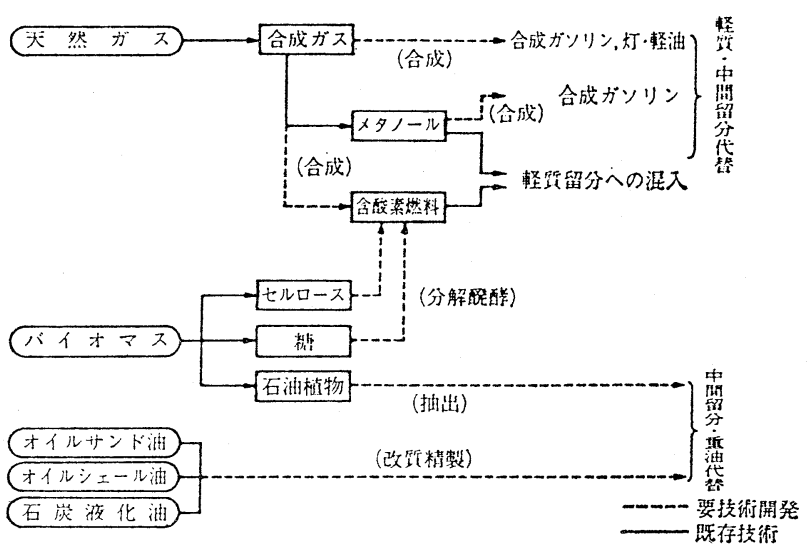

図 5 新燃料油の体系図

（2）オイルサンド油, オイルシェール油, 石炭液化 油などの石油製品代替としての利用。

（3）さとうきび，石油植物（ニーカリなど）などバ イオマス資源を原料とする睽酵アルコールおよび 炭化水素油の燃料油としての利用。

また，別な定義をすると，

2.の自動車用燃料の具備条件として常温で液体であ ることを述べたが，新燃料油とは「常温で液体である 特性を有した非石油系の燃料を総称する」と考学れば よい。3.2で述べたように1985年以降原油輸入量が3. 5 億 $\mathrm{k} \ell$ 亿抑兄られたとすると，1985年以降自動車用燃料 は不足し，1990年には，1000～1500万kl の不足とな る。自動車側の燃費改善, その他の努力を払っても, 最低1000万klの新然料油が必要と考兄られる。以下, 新然料油の個々について述べる。

\subsection{1 アルコール燃料}

図 5 の新燃料油の体系図中のオイルサンド油, オイ ルシェール油, 石炭液化油, 天然ガスからの合成油な ぞが開発途上にあることに比べて，天然ガス・石炭か らのメタノール怙よび農作物からの睽酵生成エタノ一 ル，バイオマスのセルローズ利用のエタノールなぞを 総称する含酸素燃料一アルニールの生産技術は完成に 近いるのと考兄られる。供給可能といら意味から石油 代替然料としてのアルコール燃料の意義は非常に大き い。

4.1.1.1 アルコール燃料の実用上の問題点

自動車用燃料の具備条件である可搬性, 燃料供給量 のコントロールの容易性など常温で液体である点では アルコールは石油と同等であり, 生産技術も完成の域 に近いので石油代替然料としては最短距離にあり, 後 述のごとくすでに実用化している国もある。最初から
アルコール燃料のみを燃料とする原動機 を開発することも，現在の技術をもって すれば可能なことである。しかし，現実 の問題として, 全世界で石油を燃料とし て設計製造された自動車がすでに 4 億台 以上走行していることを忘れてはならな い。日本でも3800万台の自動車が走行し ている。アルコール燃料も, この既走行 中の自動車に適用することから出発すべ きだと考光る。先にも述べたように，ア ルコール 100\%を燃料とする原動機の開 発も可能であるが, この燃料では既走行 の自動車飞適用することは種々の技術上 の問題で困難である。自動車 1 台が年間 飞消費する石油燃料は平均 $1.2 \mathrm{k} \ell$ といわれている。日 本では3800万台走行しているので, 年間石油消費量は 4500万k程度である。この10\%をアルコールで代替す

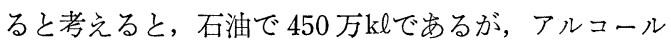

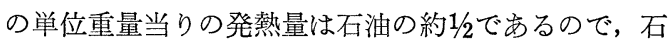
油の倍量の 900 万klのアルコールを必要とする。日本 の3800万台の 1 割の自動車をアルュール 100\% 専用の 原動機にし，残りの 9 割の自動車は石油燃料のみで走 行する方策も考光られるが，このためにはアルコール 専用原動機の開発・製造が必要であり,末端燃料流通 上にも問題が多い。石油燃料の10\%をアルコールで代 替するもらひとつの方法として，アルコールを10\%石 油に混合する方法がある。

石油燃料のらち, ガソリンはアルコールと混合する が，軽油とアルコールの混合は困難である。ガソリン に10\%のアルコールを混合した燃料は現行のガソリン エンジンをほとんど変更することなしに運転すること ができる。同一のガソリン自動車が上記のアルコール 混合燃料で走行することもできれば，ガソリンのみで 走行することもできる。このことは燃料流通上非常に 有益である。アルコールでもエタノールとメタノール では, 現行のガソリンエンジンに対するアルコールの 許容混合率は異なる。現在まで各所で検討された結果 を総合すると，現行のガソリンェンジンで走行上支障 のないアルコール混合率の限界はェタノールで $20 \%$, メタノールで15\%といえそうである。残念ながら，軽 油を燃料とするディーゼルエンジンでは, 軽油とアル コールが混合しがたいことや，アルコールのセタン価 が低いなどの問題があり，ガソリンエンジンのように 簡単には代替できない。

以上はエンジンの作働上の問題についてのアルコー 
ル燃料の特性について述べたが，さらにアルコール燃 料を現行のエンジンに適用する場合にアルコール燃料 のエンジン構成品に対する腐食の問題がある。気化器 などの然料供給部品に使われる金属材料のらら亜鉛, アルミニウム，錫系の材料に対しての腐食作用が石油 系よりも顕著である。また，然料ポンプなどに用いら れるゴム系材料など非金属材料に対しても膨潤, 硬 化, 亀裂などの材料劣化を促進する。

4.1.1.2 アルコール 混 合然料の実用例

アルコールを石油代替として使用した歴史は古い が，石油危機以降，実際に大々的に実用化しているの はブラジルと米国の二国である。筆者は1979年10月か ら11月にかけてこの二国のアルコール燃料の使用状況 を調査する機会にめぐまれたので，その実情を簡単に 述ベる。

\section{(1) ブラジル}

ブラジルの自動車の $80 \%$ が動いているサンパウロ州 を中心とした地方では，エタノール $20 \%$ エブレンドし たガソリンしか販売してない。筆者が運転した経験か ら走行上，何等の支障もなかった。ただし，ブラジル には排気規制はないので排気上の問題は別である。ブ ラジル政府はプロ・アルコール計画を推進していて 1979年には計画300万klに対して350万klの実績を収め ている。ブラジルの自動車用然料の必要量は 1500 万 $\mathrm{kl}$ /年であるので, $20 \%$ ブレンドに要するェタノールは 300万kl 必要であるが，産業用エタノールを合わせて 1979年に達成したといえる。さらに，同政府は1985年 に1000〜1300万klのエタノール生産を計画している。 エタノール $20 \%$ までの混合ならば，現行エンジンに対 策をしなくてもよいが，20\%を超えればェンジンに何 等かの対策をする必要がある。対策をするのならば， 100\%エタノール使用エンジンとしての 対策をするこ とのみ考えるといらのがブラジル 政府の考え方で, 1980年以降は30万台/年の100\%アルコール用エンジン を積んだ自動車を製造販売する計画で，1986年以降は 自動車用然料は全部アルコールにすることを目指して いた。しかし，最近の情報によると計画通りにはいか ない様子である。

(2) 米 国

米国 DOE は 1979 年 6 月 “The Report of The Alcohol Fuels Policy Review”を発行し, アルコー ル燃料を自動車用然料とする取り組み方を示してい る。自動車用然料としてのアルコールの導入は民間主 導で始まったもので, その後, 州政府などが税制面で 優遇処置を構じている現状である。DOEの計画によ
ると、ェタノールの生産量は1979年で6000万ガロンの ものを1982年には 3 億ガロンに增大することを計画し た。これは，1982年にはガソリン消費量の $3 \%$ アアル コールになり, 輸入石油量の $0.4 \%$ の軽減をアルコー ルで実施する計画である。米国のアルコールはェタノ 一ルで，主として農作物から生産され，これを10\%混 入したものをガソール (gasohol) といい，1979年 10 月現在で，アイオワ州をはじめ30州ですでに販売され ていた。その後の情報によると，レーガン政権の政策 や石油の需給緩和などからガソールの伸び率は鈍化し ている様子である。

\subsubsection{3 アルコール燃料に対する日本の現状}

日本はアルコール資源も国内には洼とんどないので アルコール燃料の使用は未だ行われていないが，フィ ジビリティ調査は1973年の石油ショック以前から行わ れている。エンジン側の適性調查は, (財)日本自動車 研究所, 東大生産技術研究所, 早大, 北大, 群馬大な ぞが行ってきた。供給側については1976年に（財）日 本産業技術振興協会が工技院の委託で, メタノールの 生産, 輸送，貯蔵に関する調査を行った。また，1980 年には日本エネルギー経済研究所とエネルギー総合工 学研究所が資源エネルギー庁の委託で, 国内外に和け るバイオマス資源によるアルコール生産に関する調査 を行った。さらに具体的アルコール利用の方針で，資 源エネルギー庁はアルコール混合ガソリンの利用に関 する大々的フィジビリティ調查を1980年より 3 ケ年計 画で次のように行っている。

(1) アルコール然料の資源量, 経済性

(口)アルコール混合ガソリンの物性, 毒性

(2) 同上の貯蔵, 不正混入防止対策

を(株) 野村総合研究所に

$\ominus$ 現用自動車への利用に関する適合性

については（財）日本自動車研究所に委託し，目下 進行中である。別に, 工業技術院の委託で1980年より 3 ケ年で（財）日本自動車研究所は「自動車用メタノ 一ル機関の利用技術に関する実用化開発」なるテーマ で研究を行っている。このように, 最近になって,よ らやくアルコール燃料に対する国家主導型の調査研究 態勢が軌道にのってきたといえる状況である。

\section{1 .2 石炭液化油}

世界の石炭量（亜䄳青炭と亜炭を除く）は地質学的 資源量で 7.7 兆 $\mathrm{t}$, 埋蔵量で 5000 億 $\mathrm{t}$ といわれてい る。今日確認されている埋蔵量でみても, 現在の消費 率で考えると全世界のエネルギー需要の 180 年分め る。この石炭エネルギーを自動車用燃料に用いる方法 


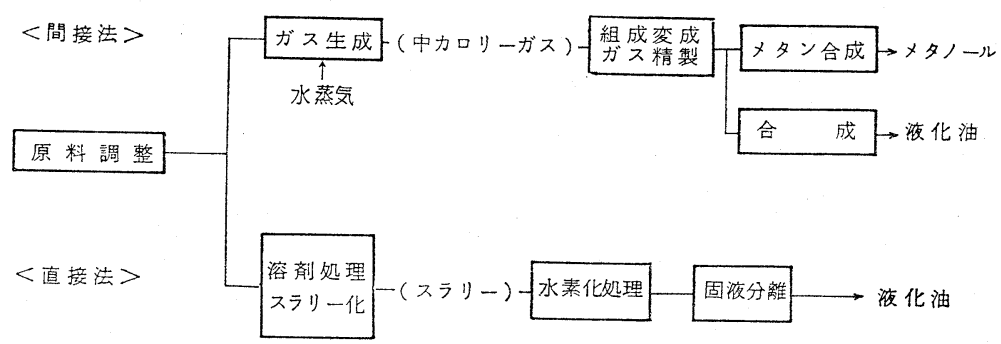

図 6 直接法と間接法のプロセス比較

はいろいろある。第 1 は石炭を直接自動車用燃料とす る方法で，1981年 6 月 3 日 GM技術センター創立 25 周 年記念にあたり，GMは石炭粉末を燃料とするタービ ン・エンジンを塔載した試作自動車を公開した。しか し，これはタービン・エンジンで，現行のエンジンに は適用できない。第2は4.1.1で述べたメタノールを 石炭から生産し，メタノールを自動車用燃料とする方 法である。第 3 は石炭による火力発電で生じた電力で 動かす電気自動車である。第 4 が本節で述べる石炭液 化油である。石炭液化油とは図6で示すプロセスで石 炭を原料として製造される液体燃料で，その性状は石 油系に類似している。

\subsubsection{1 石炭の液化技術とその用途}

石炭の液化技術は大別して直接液化法と間接液化法 があり, 直接液化法は $450^{\circ} \mathrm{C}$ 前後, 数百気圧の条件で 石炭と水素を反応させ，水素化と低分子化を行らもの であり, 第 2 次大戦中ドイッで工業化され, 褐炭から エンジン燃料を生産し，1949年をで操業した。戦後は 1965 年頃より直接液化法の研 究がアメリカで再開さ れ，第 1 次石油ショック以後西ドイッ，日本なども加 わった。現在アメリカで開発が進められているプロセ スの主要なものはSRC-I, SRC-II, EDS, H-Coal 法などである。また西ドイッでは改良 I G 法の開発が 進められている。

一方間接液化法は石炭と酸素招よび水蒸気を反応さ せ， $\mathrm{CO}$ と $\mathrm{H}_{2}$ の混合ガスを得，これを液体の炭化水 素に変換するものである。第 2 次大戦中ドイッでフィ ッシヤー・トロプシュ合成法が工業化され, 石炭から 燃料油の生産が行われ，また1955年には南了・サソ一 ル社で固定床和よび流動床反応器を用いる技術が工業 化され，以来今日まで稼動している。またサソール II が最近稼動し，サソールIII建設が行われている。間 接液化法は直接法に比ベェネルギー効率が低いとされ ているが，製品が無硫黄の高付加価值製品であり，実 用化実績があることなどが評価され，アメリカ，オ一 ストラリアでサソール・タイプのプラントの建設が計
画されている。1975年モービル社が新型ゼオライト蓝 媒Z S M-5を使ってメタノールからガソリンを合成す る方法を発表した。

石炭液化油の性状と用途はプロセスによって大きく 異なるが，直接液化油は原料石炭の化学構造が比較的 上く保持され，ナフサ留分は石油系に比ベパラフィン が少なく芳香族分とナフテンに富み，改質により高オ クタン価のガソリンが容易に得られ，直接液化ナフサ はガソリン原料として優れている。一方中間留分は異 種原子が多くクリーン燃料とはいい難く, ディーゼル 燃料, 家庭用灯油としてほ不具合で, ボイラ一然料, ジェット然料として期待される。また重質留分は比重 が高く石油系重質油之相溶性がないことを除けば，バ ンカー油として使える。間接液化油については，モー ビル法による炭化水素油は芳香族分に富み, ガソリン としてはすぐれて扮り，一方フイッシャー・トロプシ 二油は基本的にはディーゼル燃料扔よび灯油として優 れた性状をるつといえる。

\subsubsection{2 日本の石炭液化開発状況}

日本の石炭液化開発は 2 系列めり, ひとつは政府の サンシャイン計画の一環として進められて和り, 他の 系列は日米独科学技術協力として行われているもので 図 7 亿との開発体系を示す。この図で示すようにすで に数社が $1 \mathrm{t} /$ 日から $5 \mathrm{t} /$ 日の規模で運転を開始して いる。レーガン政権の出現による政府支出の削減政策 により, 日米独の科学技術協力としての日本石炭液化 技術開発（株）系列は1981年になって米国が消極的に なり，西独もこれに同調する方向で低迷している。い づれにしても, 日本の石炭液化油の開発は重質油のボ イラー用燃料などを対象としているようであり，自動 車用のガソリンや軽油の代替を目的としていないよう に思われる。

\section{2 ガス状然料}

現行の内燃機関をガス状燃料で運転することは技術 的汇問題はない。第 2 次大戦中から戦後にかけて, 木 炭や薪からガスを発生させバスを運行した記憶は新し 


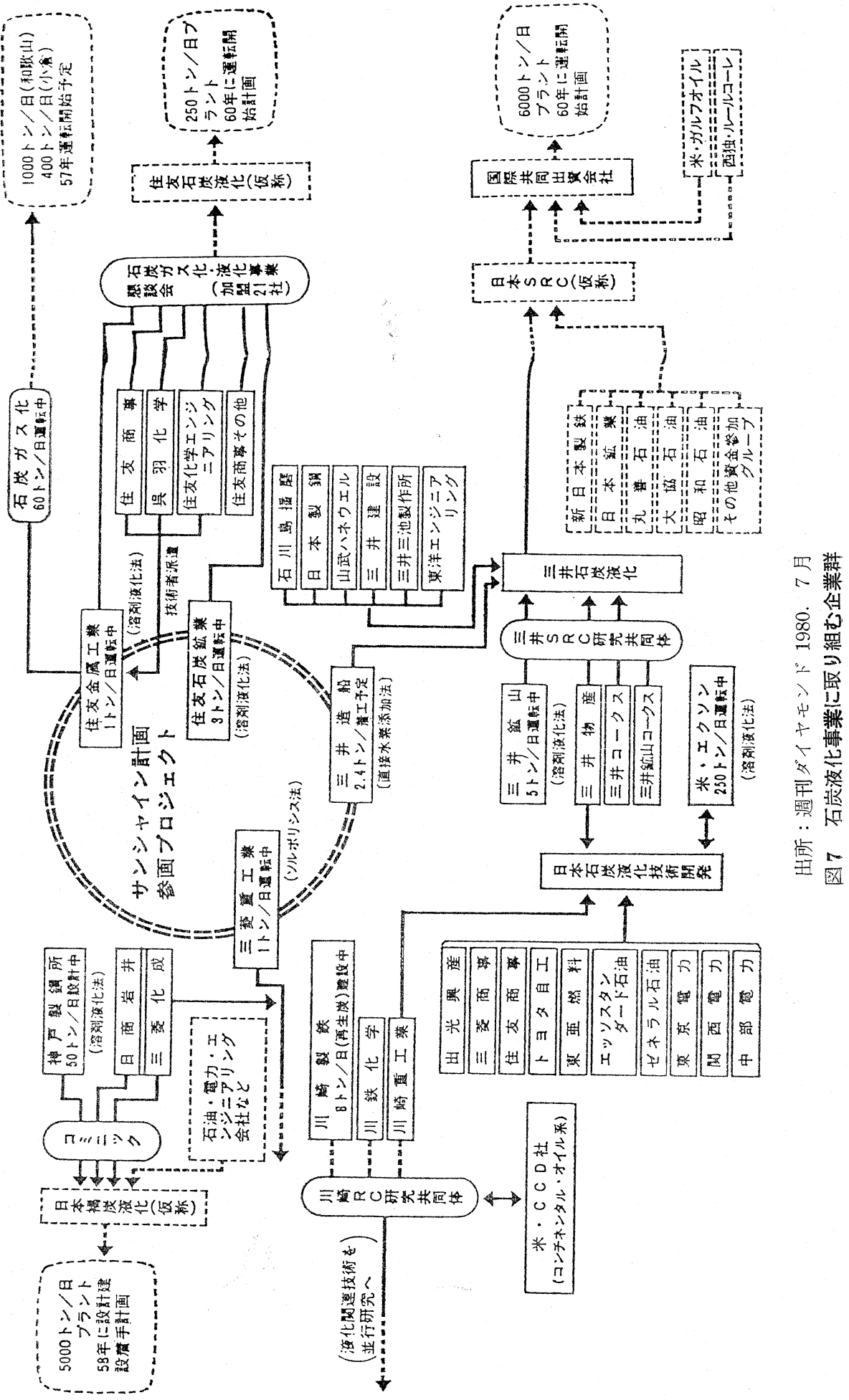


い。ガス状然料として水素, L N G, L P Gが話題に 昇っている。水素, LNGは先述した自動車用燃料の 具備条件の可搬性の点できわめて問題である。水素に ついては資源として無限であるという点から先進国で は自動車燃料としての研究が進められている。

\section{2 .1 水素然料}

石油をはじめとする化石然料資源が有限であること から，地球上に無限にある水を分解してできる水素は 将来の然料として有望である。また，水素は燃焼して エネルギーを創出し水に帰る循環性があり, 無公害で あることから1970年頃から自動車の排気公害対策とし て水素エンジンの研究が活発になった。1973年の石油 ショック以降は先述の無限燃料として, 石油代替とし て開発が進められている。水素の自動車用然料として の特性をあげると次の如くである。

(1) 火花点火エンジンにほとんどそのますで使克 る。

(2) 水素は無制限に近い希薄然焼ができる。

(3) 異状燃燒, 特にバックファイヤーが起こりやす く,これが最大出力の限界になる。

(4) 燃料の可搬性に問題がある。

自動車の場合, エンジン性能は満足すべきものにな る可能性はある。最大の問題恃(4)の可搬性である。水 素を自動車然料として運搬する手段が 2 つる。ひと つは液体水素 $\left(\mathrm{LH}_{2}\right)$, もらひとつはメタルハイドライ ド (MH) である。 $\mathrm{LH}_{2}$ は $-253^{\circ} \mathrm{C}$ の極低温で数十気 圧の高圧をかけて扔かねば液状でなくなるので， $\mathrm{LH}_{2}$ の然料タンクは高圧に耐方, 断熱性を必要とし, タン ク自身の重量で $100 \mathrm{~kg}$ 以上という重量になり，また低 温燃料を加熱する装置が必要となり，燃料の可搬性に 問題がある。水素は $\mathrm{Mg}_{2} \mathrm{Ni}$ などの金属と化学反応し て水素化金属をつくる。これをMHといい，標準状態
の水素ガス体積の $1 / 1000$ ぐらいに収納される。加熱す れば水素を放出する。これを水素の貯蔵用に利用する のがメタルハイドライド法である。粒状の MHをパイ プ飞結めてタンクとするもので, これる容積, 重量と も大となり可搬性上問題である。無限にある資源とし て水素燃料は興味あるが 20 世紀中の実用化は困難であ ろう。

\subsubsection{P G}

炭素数 3 打よび 4 の炭化水素の総称で液化石油ガス （L P G）がある。常温，常圧では気体であるが，わ ずかの加圧 $\left(1.5 \sim 8 \mathrm{~kg} / \mathrm{cm}^{2}\right)$ で液化できる。この点が L NG や水素と比べて然料タンクに対する要求が楽で 実用化され易い点である。発熱量もガソリンと同等 で, 燃焼的にも現行のガソリンェンジンに燃料供給系 を若干修正するだけで作動し，ガソリン混合気よりも 混合気の均一性が良く，世界一きびしい日本の排気規 制にる合格している。自動車としてはすでに昭和 37 年 より実用化され，現在タクシーの $80 \%$ L P Gといわ れ，30万台以上が走行している。タクシー以外飞普及 しない理由は燃料の流通上の問題であると考兄られ る。

\section{5. おわりに}

以上, 現行の自動車用原動機を大幅変更すること なく利用できる石油代替然料について概説したが，自 動車用燃料の具備条件の可搬性や他の特性から, 現行 の自動車用として石油系燃料に優るものは当分見出せ ない。日本の石油消費量飞占める自動車の消費量が14 〜 15\%と先進工業国では少ない現状からみて，他部門 のエネルギー源を極力石油以外飞転換し, 自動車, 航 空機は現行でいくといら方策も考兄られる。自動車業 界としては, エンジンの効率向上, 抵抗の低減などの 努力をさらに強化することはもちろんである。 


\title{
Fuels for Automobiles
}

\author{
Toshiyuki KoHNO
}

\section{(Japan Automobile Research Institute Inc.)}

SYNOPSIS : - Since the petroleum crisis in 1973, the automobile industry has exerted an effort toward promoting the research and development on alternative engines and fuels in consideration of dwindling oil resources. Stimulated by the gloomy oil problem, the industry is working out measures to deal with energy conservation through reviewing various alternative engines, which have been developed originally with an aim to emission control. Our expectations are, however, that there would be appeared in the near future no alternative type of engines worthy of replacing the existing internal-combustion engines. The fuels for automobile must have an excellent property on conveyance in supplies. On this point, there would be found no other better fuels than the current petroleum based fuels. For some years to come, we have to regard petroleum based fuel as the main post for automobile fuels. In this context, an effort should be made to deal with energy saving through automotive technology, while another effort should be made to develop alternative fuel without imposing greater changes on the existing engines, for example, blending of alcohol with gasoline. The coal resources, which still remain in a large quantity, should be utilized much more. The use of electric-powered vehicles should be a means for oil saving, the power of which can be charged with atomic-power or coal generated electricity. Inasmuch as battery charging still remains as a difficult problem, electric-powered vehicles will not increase greatly in the future. In addition, we cann't expect for increasing the utilization of coal and coal liquefied oil owing to their high cost. There should be also a difficulty in the utilization of hydrogen as an automobile fuel owing to troublesome carriage, though its resource exists in a limitless quantity. 